\section{Influence of tree density on climate-growth relationships in a Pinus pinaster Ait. forest in the northern mountains of Sardinia (Italy)}

\author{
Gianluigi Mazza, Andrea Cutini, Maria Chiara Manetti
}

In view of the projected increases in the frequency and duration of drought events in the Mediterranean basin, a better understanding on how differences in stand structure affect climate-growth relationships can improve and ehnance the conservation and management strategies for marginal forests in mountain areas. In this study, we examined the intra-annual variability of growth patterns and responses to climate of two maritime pine (Pinus pinaster Ait.) stands growing at contrasting tree densities at low elevation in northern Sardinia (Italy). A dendroclimatic analysis was used to assess the climategrowth relationships on monthly, seasonal and annual scales. Late spring and summer precipitations of the current year appeared to be the crucial climatic driver promoting the radial growth of trees in this mountain stand. However, summer drought was the main climate constraint, triggering negative effects on $P$. pinaster growth. Summer Palmer's drought severity index showed contrasting influence on latewood growth responses to drought conditions related to stand density, still significant also across the autumn months in the stand with the highest tree density. Our findings indicate that stands growing at high density may experience more prolonged water shortages, especially during the late summer and early autumn months. Additionally, since the early 1980s, as precipitation has decreased, the influence of previous rainy years on radial growth has been highly significant in the stand with the lowest tree density. This result suggests that such trees may explore deeper soil horizons, thus reaching water resources stored in previous rainy years, especially during periods of low precipitation.

Keywords: Pinus pinaster, Tree Rings, Stand Density, Climate-growth Relationships, Drought

\section{Introduction \\ Maritime pine (Pinus pinaster Ait.) is widely spread over the western Mediter- ranean region, the High Atlas and Tunisia in north Africa (Carrión et al. 2000). Its main populations are located in the Iberian Penin- sula, where the species has adapted to ex- tremely cold winters of central Spain and to the milder temperate climate of the Atlantic coast (Blanco et al. 1997). Population gene- tics studies have identified three main refu- gia across its range: the Atlantic coast of Portugal, southwestern Iberia, and Pantelle- ria and Sardinia in Italy (Ribeiro et al. 2001).}

$P$. pinaster has been traditionally used for timber and turpentine production (Devesa 1997), but other main uses of the species are related to recreation and soil protection. In sand dune areas, $P$. pinaster plays a very important ecological role in protecting habitats from salty winds and marine aerosol.

This species is ecologically versatile and grows on a variety of substrates and under several Mediterranean climate regimes, ranging from semi-arid to humid (Carrión et al. 2000). However, the prevailing climatic conditions in its current range are characterized by summer droughts (Correia et al. 2008).

Consiglio per la Ricerca e la sperimentazione in Agricoltura, Forestry Research Centre (CRA-SEL), v.le S. Margherita 80, I-52100 Arezzo (Italy)

@ Gianluigi Mazza (gianluigi.mazza@entecra.it)

Received: Nov 28, 2013 - Accepted: Jun 28, 2014

Citation: Mazza G, Cutini A, Manetti MC, 2014. Influence of tree density on climate-growth relationships in a Pinus pinaster Ait. forest in the northern mountains of Sardinia (Italy). iForest 8: 456-463 [online 2014-10-19] URL: http://www.sisef.it/iforest/contents/? id=ifor $1190-007$

Communicated by: Davide Ascoli
Indeed, drought-adapted provenances have been reported to better survive severe summer drought, though displaying lower vigor than mesic Atlantic provenances under favorable conditions (Alía et al. 1997).

Water stress is one of the main factors limiting the growth of this species. Moreover, predicted climatic scenarios include summer droughts of increasing severity in Mediterranean basin. Therefore, the detection of differences in drought tolerance and growth among populations on a geographical scale may allow selection of provenances better adapted to dry environments. Silvicultural treatments can ensure a greater flow of under-canopy water and reduce competition for water, light and nutrients, enhancing the growth of remnant trees (Stogsdill et al. 1989, Simonin et al. 2007). Stand density reductions by thinning have been used extensively to increase soil water availability, by reducing stand transpiration and canopy interception of precipitation, thus improving stand growth rates (Aussenac \& Granier 1988, Llorens \& Domingo 2007, Mazza et al. 2011).

Tree ring analysis is a powerful technique for detecting tree growth patterns and interannual growth variations related to climate (Fritts 1976). The intra-annual growth responses of conifers to local climatic variation have been successfully assessed using information on total ring width, earlywood and latewood widths (Campelo et al. 2006, 2013, Vieira et al. 2009, Rozas et al. 2011a, Rozas et al. 2011b). Indeed, the distinction between earlywood and latewood can lead to a higher temporal resolution of climategrowth relationships and thus provide a better understanding of the intra-annual growth responses to different climate conditions (Lebourgeois 2000, Zweifel et al. 2006, Rozas et al. 2011a).

Dendrochronological studies focused on growth responses to climate in stand with different structural characteristics have shown that growth-related climatic signals are likely to be age/size dependent (Carrer \& Urbinati 2004, De Luis et al. 2009, Vieira et al. 2009, Olivar et al. 2012, Campelo et al. 2013). Few studies have examined whether growth responses to climate variables are stable across a range of stand densities (Moreno-Gutiérrez et al. 2012, Primicia et al. 2013).

The aim of this study was to assess (i) the intra-annual variability in growth patterns and (ii) growth responses to climate in two $P$. pinaster stands growing at different tree densities at low elevation in northern Sardinia. Pine forest in the studied area has a great ecological importance for conservation purposes, as well as for the protection of soil from erosion; it has also a positive effects on tourism. A better understanding of how dif- 


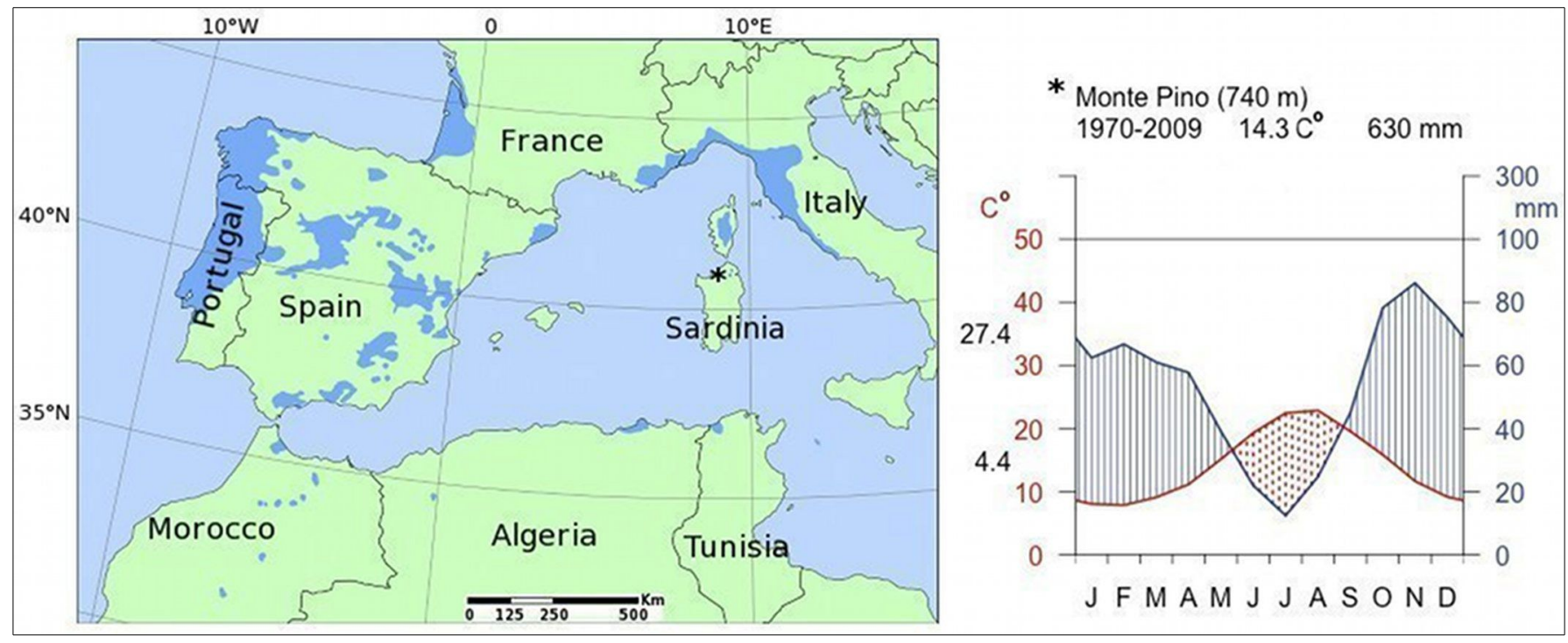

Fig. 1 - Range map of Maritime pine (Pinus pinaster Ait. - left panel). Location and Walter \& Lieth climatic diagram of the study site (right panel). The average annual temperature $\left({ }^{\circ} \mathrm{C}\right)$ and the total annual rainfall $(\mathrm{mm})$ are reported on top, while the mean maximum temperature of the warmest month and the mean minimum temperature of the coldest month are beside the left y-axis. The dotted area indicates seasonal water deficit.

ferences in stand density affect the drought tolerance of trees is relevant for future management and conservation strategies of such isolated $P$. pinaster forests over the whole Mediterranean region.

\section{Materials and Methods}

\section{Study site}

The study site is located within the forest area of Monte Pino, norther Sardinia $\left(40^{\circ}\right.$ $56^{\prime} \mathrm{N}, 09^{\circ} 22^{\prime} \mathrm{E}$ ) at $740 \mathrm{~m}$ a.s.l. (Fig. 1). Forest covers approximately 1106 ha, of which 611 ha are covered by native $P$. pinaster bio- coenoses, while Mediterranean shrubs and Quercus ilex L. coppices cover approximately 414 ha and 63 ha, respectively. Maritime pine stands lie on shallow soil derived from intrusive igneous rocks, partially metamorphic rocks, and limestone. The soil moisture regime is xeric, dry xeric, and locally udic (Costantini et al. 2014).

The climate is typically Mediterranean, with a dry summer (June, July and August are the driest months), while most rainy months are October and November (Fig. 1). The total annual rainfall is $630 \mathrm{~mm}$ and the temperature regime is thermic, and locally

Tab. 1 - Main characteristics of the pine stands studied. Mean diameter at breast height $(\mathrm{DBH})$, mean height $(\mathrm{H})$, range of the dominant/co-dominant trees cored (D), total ring (RW) width, earlywood (EW), latewood (LW), mean width (MW), standard deviation (SD) and mean sensitivity (MS), computed for the raw tree ring series; first-order serial autocorrelation (AC1), mean sensitivity (MSstd), mean interseries correlation between all series from different trees (rbar.bt) and expressed population signal (EPS), computed for the indexed tree-ring series.

\begin{tabular}{|c|c|c|c|c|c|c|c|}
\hline \multirow{3}{*}{$\begin{array}{l}\text { Parameter } \\
\text { Characte- } \\
\text { ristics }\end{array}$} & & \multicolumn{3}{|c|}{$\mathbf{A}$} & \multicolumn{3}{|c|}{ B } \\
\hline & Time span (No. years) & \multicolumn{3}{|c|}{$1963-2008(46)$} & \multicolumn{3}{|c|}{$1960-2008(49)$} \\
\hline & Tree density $\left(\mathrm{n} \mathrm{ha}^{-1}\right)$ & \multicolumn{3}{|c|}{637} & \multicolumn{3}{|c|}{318} \\
\hline & Basal area $\left(\mathrm{m} 2 \mathrm{ha}^{-1}\right)$ & \multicolumn{3}{|c|}{50.1} & \multicolumn{3}{|c|}{$\begin{array}{l}510 \\
35.6\end{array}$} \\
\hline & Mean DBH (cm) & \multicolumn{3}{|c|}{31.7} & \multicolumn{3}{|c|}{37.7} \\
\hline & Mean $\mathrm{H}(\mathrm{m})$ & \multicolumn{3}{|c|}{16.1} & \multicolumn{3}{|c|}{16.3} \\
\hline & No. cores/ No. trees & \multicolumn{3}{|c|}{$26 / 23$} & \multicolumn{3}{|c|}{$28 / 24$} \\
\hline & $D$ range $(\mathrm{cm})$ & \multicolumn{3}{|c|}{$21.3-43.6$} & \multicolumn{3}{|c|}{$20.7-48.1$} \\
\hline Chronology & Code & RW & EW & LW & RW & EW & LW \\
\hline \multirow[t]{3}{*}{ Raw data } & MW (mm) & 2.71 & 1.80 & 0.95 & 2.75 & 1.86 & 0.93 \\
\hline & $\mathrm{SD}(\mathrm{mm})$ & 1.45 & 1.04 & 0.57 & 1.32 & 0.98 & 0.56 \\
\hline & $\mathrm{MS}$ & 0.264 & 0.290 & 0.401 & 0.263 & 0.314 & 0.398 \\
\hline \multirow{4}{*}{$\begin{array}{l}\text { Indexed } \\
\text { data }\end{array}$} & $\mathrm{AC} 1$ & 0.09 & 0.06 & 0.03 & 0.02 & 0.05 & 0.01 \\
\hline & MSstd & 0.174 & 0.167 & 0.271 & 0.154 & 0.199 & 0.234 \\
\hline & rbar.bt & 0.50 & 0.34 & 0.49 & 0.47 & 0.36 & 0.49 \\
\hline & EPS & 0.94 & 0.89 & 0.94 & 0.93 & 0.90 & 0.94 \\
\hline
\end{tabular}

mesic, with an average annual temperature of $14.3{ }^{\circ} \mathrm{C}$.

Sampling sites were chosen to reflect significant differences in tree density (Tab. 1). Two even-aged pine stands planted at different spacing using native local provenances were selected. Light low thinnings, based on removal of suppressed and intermediate trees, have been occasionally carried out in both stands as well as across the whole pinewood. Both stands are characterized by a dominant and monospecific canopy layer of $P$. pinaster, with a widespread understory of Quercus ilex L., Q. suber L., Fraxinus ornus L., and other typical broadleaf maquis shrubs (Phillirea spp., Arbutus unedo L., Pistacia lentiscus L., Myrtus communis L.).

\section{Sampling and tree-ring data}

In each stand, two cores per tree were extracted at breast height from dominant trees using a 5-mm-diameter increment borer (Tab. 1). Extracted cores were mounted on wooden supports, air dried, and sanded with progressively finer sandpaper $(200 \mathrm{P}$ and $600 \mathrm{P})$ to make tree ring boundaries clearly visible under magnification. Earlywood (EW) and latewood (LW) widths were measured at a precision of $0.01 \mathrm{~mm}$ by a computer-linked mechanical platform under a stereoscope, and total ring (RW) widths were calculated as the sum of the two measurements for each ring. The earlywood/latewood transition was visually identified by a detectable changing in cell wall thickness, resulting in a band of darker cells.

Each ring width series was first visually checked and then statistically verified for cross-dating and measurement errors using 
the dendrochronology program library "dplR" developed for the $\mathrm{R}^{\circledR}$ package by Bunn (2010). Mean chronologies were truncated at a minimum sample size of $<5$ series.

\section{Chronology computation and data analysis}

To remove age-related growth trends and competition effects, a one-step detrending was applied to each individual series, using the packages dplR (Bunn 2008). A smoothing cubic spline curve with a $50 \%$ frequency cut-off and response period of 30 years was fitted to each individual ringwidth series. The indexes were calculated as ratios between the actual and fitted values. The index values were then pre-whitened using an autoregressive model selected on the basis of the minimum Akaike Information Criterion (AIC) and combined across all series using a bi-weight robust estimation of the mean to exclude the influence of the outliers (Cook et al. 1990). The first-order seria autocorrelation $(\mathrm{AC} 1)$ was used to detect the persistence retained after the standardization. The signal strength of the tree-ring series was assessed using both the mean interseries correlation between all series from different trees (rbar.bt) and the expressed population signal (EPS), which is commonly adopted as a criterion for assessing the reliability of chronologies (Wigley et al. 1984).

To explore common growth patterns between stand types we expressed the characteristics of our time series in the frequency domain. In this case, the spectral density was estimated by a smoothed periodogram using a fast Fourier transform (Ghil et al. 2002), which yielded an estimate of the common variance associated with cycles at each frequency.

\section{Climate-growth relationships}

Due to the lack of representative meteorological data for the whole period covered by our chronologies, datasets from the Climate Research Unit (CRU, University of East Anglia, UK) were used to obtain mean monthly maximum temperatures and precipitation for the period 1951-2009 and the Palmer drought severity index (PDSI) for the period 1951-2002 (CRU self-calibrating PDSI), gridded on a $0.5 \times 0.5$ degree network. The chosen climate data, corresponding to the closest grid point to the geographical area in which the pinewood is located, were taken from the website of the Royal Netherlands Meteorological Institute (http://climexp.kn$\mathrm{mi} . \mathrm{nl} /$ ).

The PDSI uses air temperature, accumulated rainfall and field water-holding capacity to compute a standardized measure of soil moisture ranging from -6 to 6 , the limits of which correspond to extremely dry and extremely wet soil conditions, respectively (Dai et al. 2004).

To assess the presence of climatic trends, we applied the Mann-Kendall non-parametric test (Brunetti et al. 2006, Hamed 2008). Years characterized by the lowest amount of precipitation were identified using the Standardized Anomaly Index (SAI), calculated as $I t=(R t-\mu) / \sigma$, where $R t$ denotes the total annual precipitation, $\mu$ and $\sigma$ are mean and standard deviation of the long-term precipitation, respectively (Katz \& Glantz 1986).

The influence of climate on tree-ring growth on a monthly and seasonal scale was investigated using a correlation function (CF) analysis (Fritts 1976). We used 36 independent monthly climate variables sequenced from October of the year prior to growth $(t-1)$ to September of the year of growth $(t)$. Pearson's correlation coefficients were tested for significance using the $95 \%$ percentile range method after a bootstrap process with 1000 replications, using the "bootRes" routine in the $\mathrm{R}^{\circledR}$ package (Zang \& Biondi 2013). Standardized coefficients were obtained by dividing the mean correlations by their standard deviations after the bootstrap replications (i.e., considering each test as independent).

The effects of the previous year's precipitation on tree growth were tested with the Pearson's correlations using the annual precipitation (from previous December to September of the current year) and precipitation cumulated over the 1-4 years prior to the year of tree ring formation (from October $t-n$ to September $t$, with $n$ ranging from 1 to 4 ).
The Bonferroni method was used for multiple comparison correction of the significance levels.

To assess the influence of the previous year's precipitation on tree growth over time, a 10-year running linear correlation was applied. This analysis produced a sequential correlation between standardized RW and precipitation sums for 1-4 years, adding at each step one new year and removing the oldest one from the running window (Sarris et al. 2007). The correlation coefficients were placed at the center $\left(5^{\text {th }}\right.$ year $)$ of each 10 -year period.

\section{Results}

\section{Tree-ring growth patterns}

The two stands differed mainly in tree density, with the number of trees in stand A being double that in the stand B (Tab. 1). Synchronization between the mean chronologies of the tree-ring widths was highly significant. The Gleichläufigkeit (GLK - Schweingruber 1988) values ranged from 0.74 to 0.76 between the RW and EW chronologies of the two stands to 0.86 between the LW chronologies. EW was wider than LW for both stands (Fig. 2) and was characterized by smaller relative changes between consecutive rings than $\mathrm{LW}$, as indicated by the MS values. No significant differences in the main dendrochronological characteristics were detected between the two stands, although mean RW and EW were slightly higher in the stand with the lower tree density (B).

After detrending, LW exhibited a stronger common growth signal than EW, as revealed by the higher values of the rbar.bt and EPS statistics.

The spectral density of the indexed chronologies displayed common growth patterns in the frequency domain, and the LW chronologies exhibited higher variance than RW and EW for both high and low frequencies (Fig. 3).

\section{Growth responses to climate}

The EW, LW, and RW chronologies revealed a large amount of the year-to-year
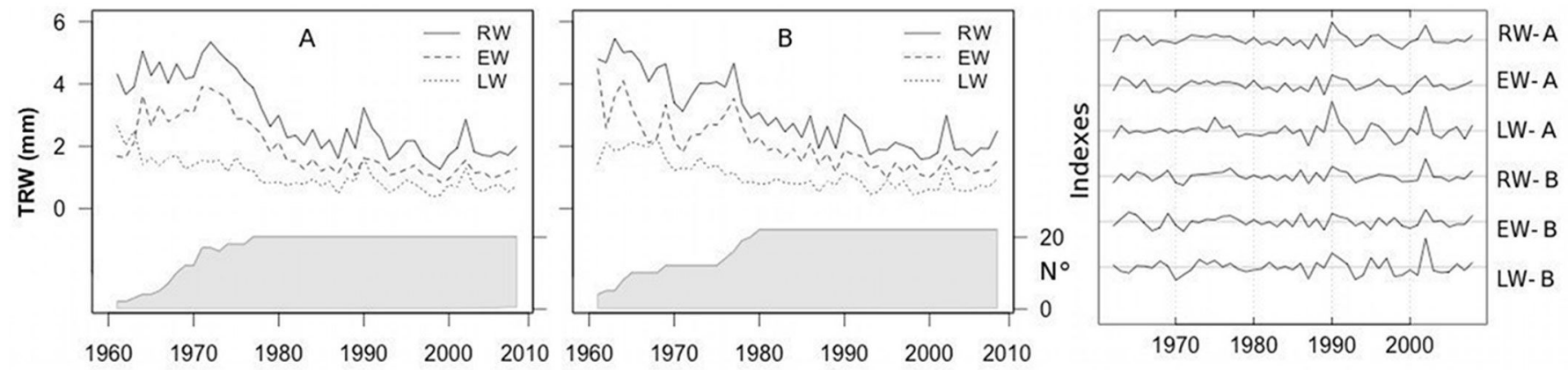

Fig. 2 - Mean raw and standardized RW, EW and LW chronologies for each stand. (A): high-density stand; (B): low-density stand. The shaded areas indicate the number of trees. 
Fig. 3 - Spectral density of mean standardized RW, EW and LW stand chronologies.

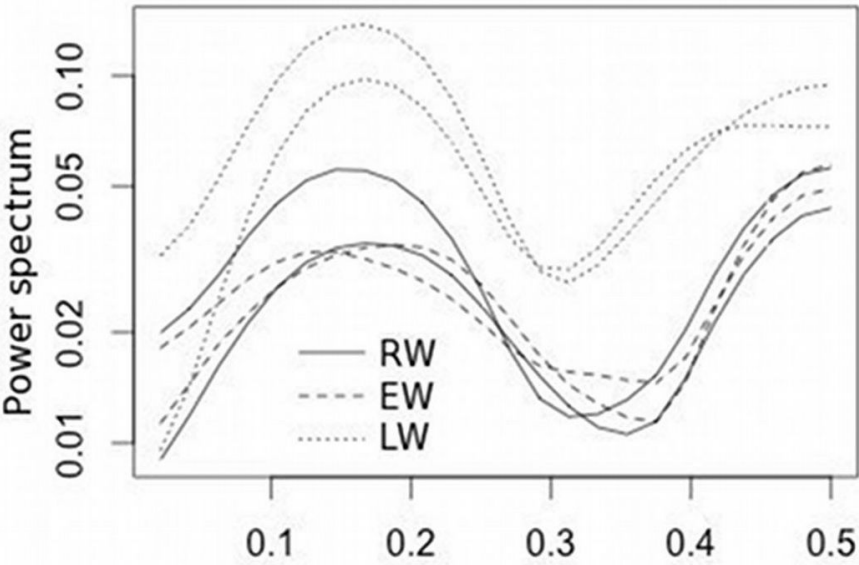

Frequency (bandwidth $=0.04$ )

growth variation shared by trees. Significant differences in climate-growth relationships appeared among EW, LW, and RW within both stands and between the A and B stands, especially with respect to the PDSI.

Late-spring and summer precipitation of the current year exerted a positive influence on $P$. pinaster growth at our study sites. In stand A, the tree-ring width (RW) was positively correlated with precipitation in May and August (Fig. 4); in particular, significant correlation was found between EW and the precipitation of May and between LW and the precipitation of August. In addition, $P$. pinaster in the stand $\mathrm{B}$ showed a positive correlation with June and August rainfall. Tree growth in both stands was negatively affected by summer maximum temperatures in the current year, although contrasting climate growth response for August temperature was found in earlywood and latewood (Fig. 4).

Summer drought appeared to be the climatic factor limiting $P$. pinaster tree growth in both stands (Fig. 4). On the other hand, the effect of prolonged drought conditions until September exhibited a contrasting influence of stand density on climate-growth relationships. Indeed, a significant and positive correlation between both RW and LW and the
PDSI of September in the current year was found only in stand A (Fig. 4).

The climate-growth analysis on a seasonal scale highlighted the cumulative effect of climate variables on tree growth, revealing even more remarkable differences in growth responses to climate between the two stands (Fig. 5). Indeed, distinct results were obtained for summer precipitation, winter maximum temperatures and summer-autumn PDSI of the current year. The main contrasting climate-growth correlations were the positive effect of summer (June-July-August) precipitation on $\mathrm{EW}$ formation in stand $B$ and summer-autumn (June to November) PDSI on LW formation in stand A (Fig. 5). Moreover, a positive effect of winter (December-January-February) maximum temperature on $\mathrm{EW}$ formation in stand $\mathrm{A}$ and a negative effect of summer maximum temperature on RW formation in stand $\mathrm{B}$ were found (Fig. 5).

On a yearly basis, correlations between precipitation and tree growth were found to be higher for lower stand density when the precipitation accumulated over the previous years was considered. Indeed, considering the current year, significant correlation coefficients were found for stand B between RW and EW and the precipitation accumulated over 2-3 and 3-4 years, respectively (Fig. 5).

The $\mathrm{Z}$ scores of SAI exhibited a decrease in precipitation amounts during the last decades of the $20^{\text {th }}$ century (Fig. 6). During this period, RW and EW chronologies showed sig-

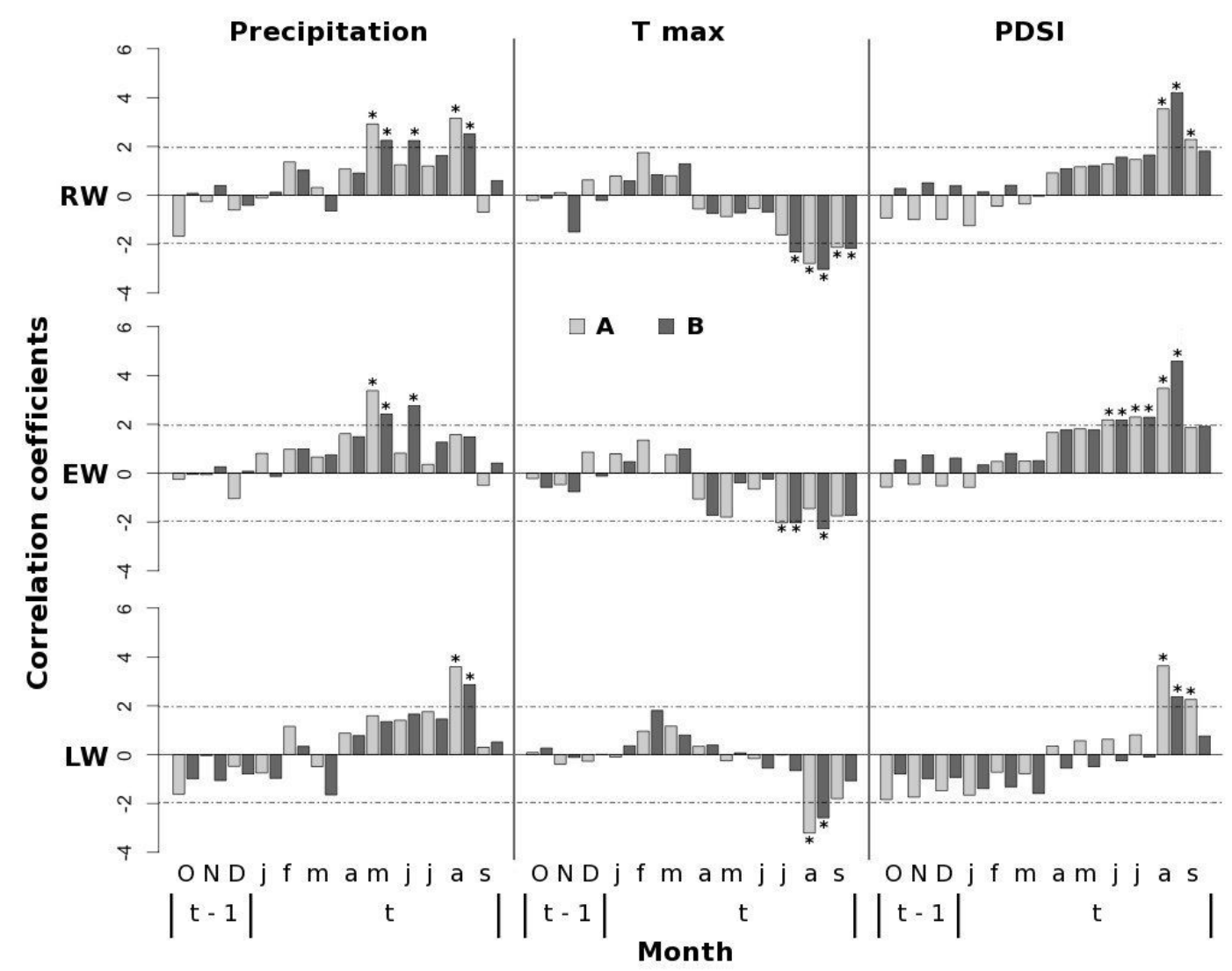

Fig. 4 - Bootstrapped correlation functions between standardized RW, EW and LW chronologies and monthly climate variables (total precipitation, maximum temperature, and PDSI) from previous October to current September. Horizontal dashed lines indicate the significance level: values above $|1.96|$ are significant at $\mathrm{p}<0.05$. (A): high-density stand; (B): low-density stand. 
Fig. 5 - (a) Bootstrapped correlation functions on seasonal scale. (W): Winter; (Sp): Spring; (Su): Summer; (A): Autumn. Horizontal dashed lines indicate the significance level: values above $|1.96|$ are significant at $\mathrm{p}<0.05$. (b): Correlation coefficients between standardized RW, EW and LW chronologies and precipitation cumulated over the 1-4 years prior to the year $(t)$ of tree ring formation. $(*)$ : $\mathrm{p}<0.05 ;(* *): \mathrm{p}<0.01$ after the Bonferroni correction for multiple comparisons. (A): high-density stand; $(\mathrm{B}=$ : lowdensity stand.

Fig. 6 - Correlation coefficients from 10 -year running linear correlations between standardized RW (a) and EW (b) chronologies and precipitation accumulated over the 1-3 years prior to the year of tree ring formation (Sum1,

Sum2 and Sum3, respectively), from 1966 to 2003 . (A): high-density stand; (B): low-density stand. The shaded area indicates the lowest rainy periods highlighted by decadal means of the Standardized Anomaly Index (SAI).
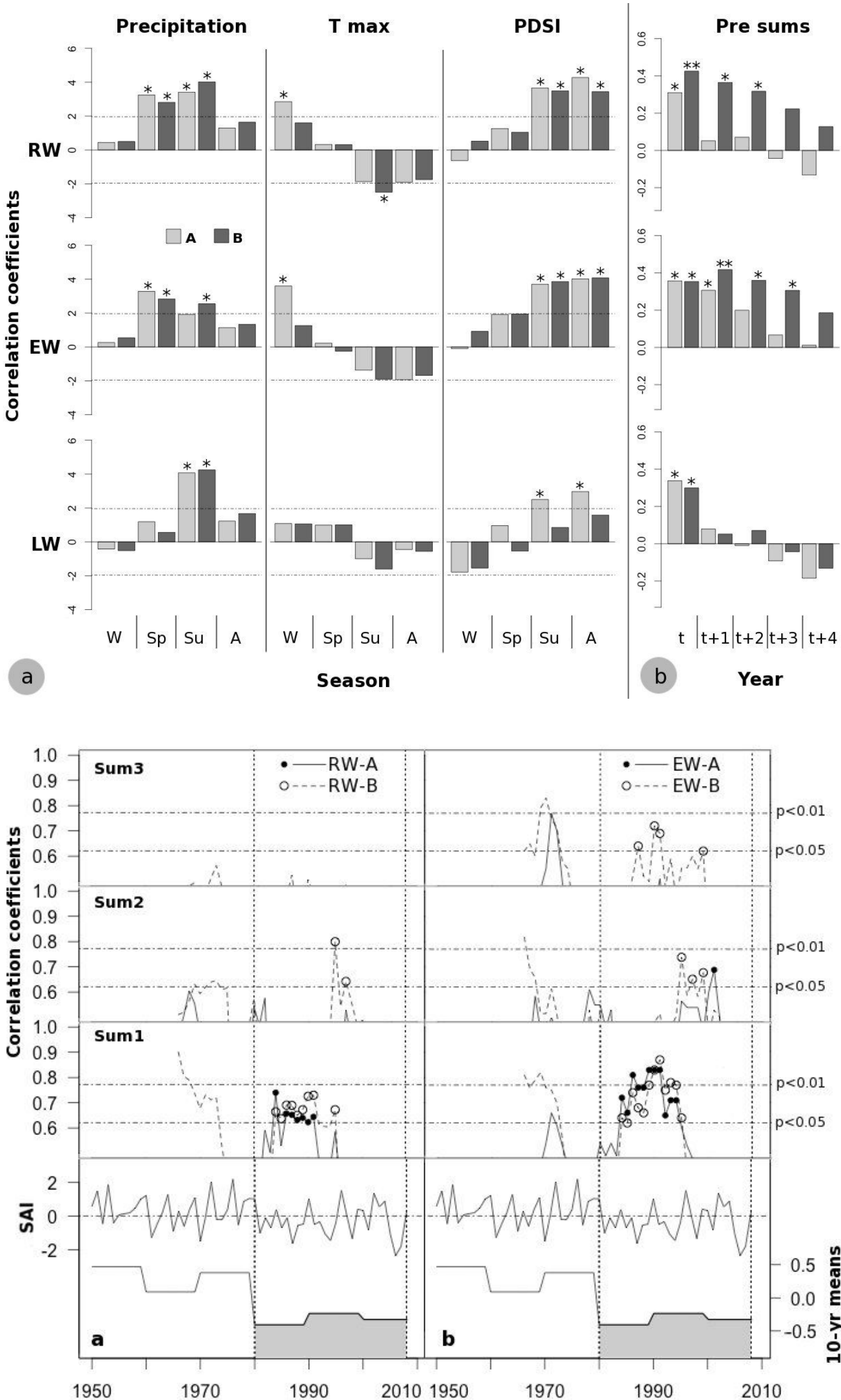
nificant high correlation with the precipitation accumulated over the previous year. The effect of stand density seems to be more evident considering the significance of the precipitation accumulated over 3 and 4 years on EW in stand B (Fig. 6). The effect of stand density became more evident when EW and precipitation accumulated over 3 and 4 years were considered, as shown by higher and significant correlations found for stand $\mathrm{B}$ (Fig. 6).

\section{Discussion}

Summer drought was found to be the primary climate constraint, triggering negative effects on $P$. pinaster growth. High temperatures along with low amounts of rainfall in August negatively influence RW growth and limit LW formation due to the reduction in water availability caused by the increase in evapotranspiration and soil water evaporation (Campelo et al. 2006, Vieira et al. 2009). Several dendrochronological studies have found tree-ring growth of Pinus sp. at low elevations to be limited by water availability during summer (Andreu et al. 2007, Bogino \& Bravo 2008, Dorado Liñán et al 2011). Indeed, the August PDSI had the highest correlation coefficients for both stands, affecting both EW and LW formation (Fig. 4).

On the other hand, precipitations occurring in late-spring and summer of the current year appeared to be the crucial climatic driver that foster the radial growth of Maritime pine in the mountain population studied in northern Sardinia. A positive influence of late-spring and early-summer precipitation (May-June) on tree growth was also observed for $P$. pinaster forests in central and northwestern Spain (Bogino \& Bravo 2008, Rozas et al. 2011) and in the northwestern coast of Portugal (Vieira et al. 2009), suggesting that the radial growth of $P$. pinaster is limited by water deficit during the growing season. These results highlight the positive effects of spring and early-summer precipitation, resulting in a common fingerprint for $P$. pinaster populations growing under typical Mediterranean climate. Indeed, high correlations between May-June precipitations and EW formation (Fig. 4) suggest that the maximum number of cambium cells occurs in spring, according to the first increment peak of the bimodal pattern originated from a double reactivation of cambial activity in spring and autumn (Vieira et al. 2014).

The influence of PDSI on LW growth during summer months was higher in the stand with the highest tree density and remained significant until September (Fig. 4), suggesting that $\mathrm{LW}$ formation in this stand is more sensitive to drought conditions during latesummer period.

The contrasting growth response to climate of the two stands were clearer on a seasonal scale. In the stand with the higher trees density the winter maximum temperature was positively correlated both with RW and EW widths, probably due to more favorable microclimatic conditions promoting photosynthesis during the winter (Fig. 5). On the other hand, in this stand water deficit affected the radial growth of trees during LW formation in summer and autumn, as revealed by the high and significant influence of PDSI on LW widths (Fig. 5). Considering that LW formation showed the highest intraannual variance in the frequency domain, as shown by spectral density of the mean standardized chronologies, the August PDSI and, more generally, a severe summer drought may be the main factor affecting radial growth.

The significant influence of late-summer and early-autumn PDSI also on EW formation could be related to a gradual earlywood/latewood transition due to the formation of bands of latewood-like tracheids with darker cells within the late earlywood (De Micco et al. 2007). They were probably produced as a consequence of drier summer conditions following a wetter period (Cherubini et al. 2003), prior to the regular latewood formation. Moreover, EW in the stand with the lower tree density was also positively and significantly correlated with summer precipitation. This result suggest that trees are able to utilize a greater amount of water reaching the soil during the summer months, due to low interception loss because of the presence of gaps within the canopy cover (Mazza et al. 2011).

The inter-tree competition for water availability can make trees growing in high-density stands more vulnerable to drought conditions than trees growing in lower-density stands. In a semiarid ecosystem in Murcia (in southeastern Spain), Pinus halepensis Mill. trees in closed stands were found to be more prone to water shortage than pines in open woodlands (Moreno-Gutiérrez et al. 2012). In a Pinus pinea L. pinewood in central Italy, the net under-canopy precipitation was always found to be greater in a thinned stand than in an unthinned stand, especially for low precipitation amounts, because of the greater interception by the tree canopy (Mazza et al. 2011). This pattern was observed especially for the dry summer months, when the net under-canopy precipitation in the unthinned area decreased by nearly $23 \%$. Moreover, the effect on growth of several years of drought was found more severe than the sums of the effects of single years of drought (Kramer et al. 2000), because consecutive years of drought reduce the water content stored in the previous rainy years. Thus, as precipitation decreases, trees become increasingly dependent on moisture from deeper soil horizons, as found in $P$. pinea (Mazza \& Manetti 2013) and Pinus brutia Ten. (Sarris et al. 2007) growing in Mediterranean climate. This can be due to the extensive root system, which permits the mature trees to exploit a larger soil volume, or deeper water resources.

At our study site, after the early 1980s, as precipitation decreased, the influence of previous rainy years on tree growth was highly significant for the stand with the lower tree density, especially for EW formation (Fig. 6). As the upper soil layers dry up faster in open woodland than in dense forested stands (Raz-Yaseef et al. 2010), pines in thin stands during periods of low amounts of precipitation may be highly dependent on precipitation accumulated in deeper soil layers during previous rainy years.

\section{Conclusions}

This study identified the main climatic drivers affecting the radial growth of $P$. pinaster in a northern Sardinian mountain population, and highlighted the influence of stand density on growth responses of trees to drought conditions. In view of the projected increases in frequency and duration of drought periods in the Mediterranean basin, our findings may help in the adoption of silvicultural practices aimed at the conservation and management of marginal $P$. pinaster populations in mountainous areas. Stands growing at high tree densities may experience more prolonged water shortages, particularly during the driest months. On the other hand, the influence of previous rainy years on radial growth has been highly significant in the stand with the lowest tree density, suggesting that trees grown in low-density stands may explore deeper soil horizons, thus reaching water resources stored in previous rainy years, especially during periods of low precipitation.

The results of future studies on the influence of trees stand structure on climategrowth relationships should be taken into account in the design of mitigation and conservation strategies based on silvicultural management for the purpose of improving the resilience of forests under climate change scenarios projected for the Mediterranean basin.

\section{Acknowledgments}

This research was funded by the Ente Foreste della Sardegna within the research projects "Silvicultural practices for the renaturalization of pure conifer plantations" and "Biomass allocation and carbon stocks in $P i$ nus spp. stands in Sardinia". We are grateful to the personnel from Ente Foreste della Sardegna for site access and collaboration. We also wish to thank the colleagues from the Forestry Research Center (CRA-SEL) who helped in the field work and the two anonymous reviewers for their useful comments on an earlier version of the manuscript. 


\section{References}

Alía R, Moro J, Denis JB (1997). Performance of Pinus pinaster provenances in Spain: interpretation of the genotype by environment interaction. Canadian Journal of Forest Research 27: 15481559. - doi: 10.1139/X97-122

Andreu L, Gutiérrez E, Macias M, Ribas M, Bosh O, Camarero JJ (2007). Climate increases regional tree-growth variability in Iberian pine forests. Global Change Biology 13: 804-815. - doi: 10.1111/j.1365-2486.2007.01322.x

Aussenac G, Granier A (1988). Effect of thinning on water stress and growth in Douglas fir. Canadian Journal of Forest Research 18 (1): 100-105. - doi: 10.1139/x88-015

Blanco E, Casado M, Costa M, Escribano R, Gracía Antón M, Génova M, Gómez Manzaneque G, Gomez Manzanaque F, Moreno J, Morla C, Regato P, Sainz Ollero H (1997). Los bosques ibéricos: una interpretación geobotánica [Iberians forests: a geobotanical interpretation]. Editorial Planeta, Barcelona, Spain, pp. 572. [in Spanish]

Bogino SM, Bravo F (2008). Growth response of Pinus pinaster Ait. to climatic variables in central Spanish forests. Annals of Forest Science 65 (5): 506. - doi: 10.1051/forest:2008025

Brunetti M, Maugeri M, Monti F, Nanni T (2006). Temperature and precipitation in Italy in the last two centuries from homogenised instrumental time series. International Journal of Climatology 26: 345-381. - doi: 10.1002/joc. 1251

Bunn AG (2008). A dendrochronology program library in R (dplR). Dendrochronologia 26: 115 124. - doi: 10.1016/j.dendro.2008.01.002

Bunn AG (2010). Statistical and visual crossdating in $\mathrm{R}$ using the dplR library. Dendrochronologia 28: 251-258. - doi: 10.1016/j.dendro.200 9.12.001

Campelo F, Nabais C, Freitas H, Gutiérrez E (2006). Climatic significance of tree-ring width and intra-annual density fluctuations in Pinus pinea from dry Mediterranean area in Portugal. Annals of Forest Science 64: 229-238. - doi: 10.1051/forest:2006107

Campelo F, Nabais C, Vieira J (2013). Tree-ring growth and intra-annual density fluctuations of Pinus pinaster responses to climate: does size matter? Trees 27: 763-772. - doi: 10.1007/s004 68-012-0831-3

Carrer M, Urbinati C (2004). Age-dependent treering growth responses to climate in Larix decidua and Pinus cembra. Ecology 85: 730-740. doi: 10.1890/02-0478

Carrión JS, Navarro C, Navarro J, Munuera M (2000). The distribution of cluster pine (Pinus pinaster) in Spain as derived from palaeoecological data: relationships with phytosociological classification. The Holocene 10 (2): 243-252. doi: 10.1191/095968300676937462

Cherubini P, Gartner BL, Tognetti R, Bräker OU, Schoch W, Innes JL (2003). Identification, measurement and interpretation of tree rings in woody species from Mediterranean climates. Biological Reviews 78: 119-148. - doi: 10.1017/ S1464793102006000
Cook ER, Briffa KR, Shiyatov S, Mazepa V (1990). Tree-ring standardization and growth trend estimation. In: "Methods of Dendrochronology. Applications in the environmental sciences" (Cook ER, Kairiukstis LA eds). Kluwer Academic Publishers, Dordrecht, The Netherlands, pp. 104-123.

Correia I, Almeida MH, Aguar A, Alía R, David TS, Pereira JS (2008). Variations in growth, survival and carbon isotope composition (delta (13)C) among Pinus pinaster populations of different geographic origins. Tree Physiology 28: 1545-1552. - doi: 10.1093/treephys/28.10.1545

Costantini EAC, Barbetti R, Fantappié M, L'Abate G, Lorenzetti R, Napoli R, Marchetti A, Rivieccio $R$ (2014). The soil map of Italy: a hierarchy of geodatabases, from soil regions to subsystems. In: "GlobalSoilMap: basis of the global spatial soil information system" (Arrouays D, McKenzie N, Hempel J, Richer de Forges A, McBratney AB eds). CRC Press, Taylor \& Francis Group, LLC, Boca Raton, FL, USA, pp. 109112. [online] URL: http://books.google.com/ books?id=S5ClAgAAQBAJ

Dai A, Trenberth KE, Qian T (2004). A global data set of Palmer drought severity index for 1870-2002: relationship with soil moisture and effects of surface warming. Jouranl of Hydrometeorology 5: 1117-1130. - doi: 10.1175/JHM386.1

De Luis M, Novak K, Cufar K, Raventós J (2009). Size mediated climate-growth relationships in Pinus halepensis and Pinus pinea. Trees 23 (5): 1065-1073. - doi: 10.1007/s00468-009-0349-5

De Micco V, Saurer M, Aronne G, Tognetti R, Cherubini P (2007). Variations of wood anatomy and $\delta^{13} \mathrm{C}$ within-tree rings of coastal Pinus pinaster showing intra-annual density fluctuations. IAWA Journal 28 (1): 61-74. - doi: 10.1163/22941932-90001619

Devesa JA (1997). Plantas con semilla [Seed plants]. In: "Botanica" (Izco J ed). McGraw-Hill, Madrid, Spain, pp. 379-580. [in Spanish]

Dorado Liñán I, Gutiérrez E, Heinrich I, AndreuHayles L, Munta'n E, Campelo F, Helle G (2011). Age effects and climate response in trees: a multi-proxy tree-ring test in old-growth life stages. European Journal of Forest Research 131: 933-944. - doi: 10.1007/s10342-011-0566-

Fritts HC (1976). Tree ring and climate. Academic Press, London, UK, pp. 582. [online] URL: http://books.google.com/books?\&id=mkjsuFdwjeoC

Ghil M, Allen MR, Dettinger MD, Ide K, Kondrashov D, Mann ME, Robertson AW, Saunders A, Tian Y, Varadi F, Yiou P (2002). Advanced spectral methods for climatic time series. Reviews of Geophisics 40 (1): 1-41. - doi: 10.1029/ 2001RG000092

Hamed KH (2008). Trend detection in hydrologic data: the Mann-Kendall trend test under the scaling hypothesis. Journal of Hydrology 349: 350363. - doi: 10.1016/j.jhydrol.2007.11.009

Katz RW, Glantz MH (1986). Anatomy of a rainfall index. Monthly Weather Review 114: 764-
771. - doi: 10.1175/1520-0493(1986)114<076 4:AOARI $>2.0 . \mathrm{CO} ; 2$

Kramer K, Leinonen I, Loustau D (2000). The importance of phenology for the evaluation of impact of climate change on growth of boreal, temperate and Mediterranean forests ecosystems: an overview. International Journal of Biometeorology 44: 67-75. - doi: 10.1007/s004840000066 Lebourgeois F (2000). Climatic signals in earlywood, latewood and total ring width of Corsican pine from western France. Annals of Forest Science 57: 155-164. - doi: 10.1051/forest:2000166 Llorens P, Domingo F (2007). Rainfall partitioning by vegetation under Mediterranean conditions. a review of studies in Europe. Journal of Hydrology 335: 37-54. - doi: 10.1016/j.jhydrol. 2006.10.032

Mazza G, Amorini E, Cutini A, Manetti MC (2011). The influence of thinning on rainfall interception by Pinus pinea L. in Mediterranean coastal stands (Castel Fusano-Rome). Annals of Forest Science 68: 1323-1332. - doi: 10.1007/ s13595-011-0142-7

Mazza G, Manetti MC (2013). Growth rate and climate responses of Pinus pinea L. in Italian coastal stands over the last century. Climatic Change 121: 713-725. - doi: 10.1007/s10584013-0933-y

Moreno-Gutiérrez C, Battipaglia G, Cherubini P, Saurer M, Nicolás E, Contreras S, Querejeta JI (2012). Stand structure modulates the long-term vulnerability of Pinus halepensis to climatic drought in a semiarid Mediterranean ecosystem. Plant, Cell and Environment 35: 1026-1039. doi: 10.1111/j.1365-3040.2011.02469.x

Olivar J, Bogino S, Spiecker H, Bravo F (2012). Climate impact on growth dynamic and intra-annual density fluctuations in Aleppo pine (Pinus halepensis) trees of different crown classes. Dendrochronologia 30 (2012) 35-47. - doi: 10.1016/ j.dendro.2011.06.001

Primicia I, Camarero JJ, Imbert JB, Castillo FJ (2013). Effects of thinning and canopy type on growth dynamics of Pinus sylvestris: inter-annual variations and intra-annual interactions with microclimate. European Journal of Forest Research 132: 121-135. - doi: 10.1007/s10342-01 2-0662-1

Raz-Yaseef N, Rotenberg E, Yakir D (2010). Effects of spatial variations in soil evaporation caused by tree shading on water flux partitioning in a semi-arid pine forest. Agricultural and Forest Meteorology 150: 454-462. - doi: 10.1016/j. agrformet.2010.01.010

Ribeiro MM, Plomion C, Petit R, Vendramin GG, Szmidt AE (2001). Variation of chloroplast simple-sequence repeats in Portuguese maritime pine (Pinus pinaster Ait.). Theoretical and Applied Genetics 102: 97-103. - doi: 10.1007/s001 220051623

Rozas V, Zas R, García-González I (2011a). Contrasting effects of water availability on Pinus pinaster radial growth near the transition between the Atlantic and Mediterranean biogeographical regions in NW Spain. European Journal of Forest Research 130: 959-970. - doi: 
10.1007/s10342-011-0494-4

Rozas V, García-González I, Zas R (2011b). Climatic control of intra-annual wood density fluctuations of Pinus pinaster in NW Spain. Trees 25:443-453. - doi: 10.1007/s00468-010-0519-5

Sarris D, Christoduolakis D, Körner C (2007). Recent decline in precipitation and tree growth in the eastern Mediterranean. Global Change Biology 13 (6): 1187-1200. - doi: 10.1111/j.1365-24 86.2007.01348.x

Schweingruber FH (1988). Tree rings: basics and applications of dendrochronology. Kluwer Academic Publishers, Dordrecht, The Netherlands, pp. 276.

Simonin K, Kolb TE, Montes-Helu M, Koch GW (2007). The influence of thinning on components of stand water balance in a ponderosa pine stand during and after extreme drought. Agricultural and Forest Meteorology 143: 266-276. - doi: 10.1016/j.agrformet.2007.01.003

Stogsdill WR, Wittwer RF, Hennessey TC, Dougherty PM (1989). Relationship between throughfall and stand density in a Pinus taeda plantation. Forest Ecology and Management 29: 105-113. - doi: 10.1016/0378-1127(89)90059-5

Vieira J, Campelo F, Nabais C (2009). Age-dependent responses of tree-ring growth and intraannual density fluctuations of Pinus pinaster to Mediterranean climate. Trees 23: 257-265. - doi: 10.1007/s00468-008-0273-0

Vieira J, Rossi S, Campelo F, Nabais C (2014). Are neighboring trees in tune? Wood formation in Pinus pinaster. European Journal of Forest Research 133: 41-50. - doi: 10.1007/s10342- 013-0734-x

Wigley TML, Briffa KR, Jones PD (1984). On the average value of correlated time series, with applications in dendroclimatology and hydrometeorology. Journal of Climate and Applied Meteorology 23: 201-210.

Zang C, Biondi F (2013). Dendroclimatic calibration in R: the bootRes package for response and correlation function analysis. Dendrochronologia 31: 68-74. - doi: 10.1016/j.dendro.2012.08.001 Zweifel R, Zimmermann L, Zeugin F, Newbery DM (2006). Intra-annual radial growth and water relations of trees: implications towards a growth mechanism. Journal of Experimental Botany 57: 1445-1459. - doi: 10.1093/jxb/erj125 